\title{
MJN NURSING EXPERIENCE IN PEDIATRIC MEDICATION SAFETY
}

\author{
Margareta Hesti Rahayu ${ }^{1 *}$, Fitri Haryanti ${ }^{2}$, Sri Mulatsih ${ }^{3}$ \\ ${ }^{1}$ School of Health Sciences of Panti Rapih, Yogyakarta, Indonesia \\ ${ }^{2}$ Child and Maternity Nursing Department, Faculty of Medicine, Public Health, and Nursing, Universitas \\ Gadjah Mada, Yogyakarta, Indonesia \\ ${ }^{3}$ Pediatric Health Department, Faculty of Medicine, Public Health, and Nursing, Universitas Gadjah Mada, \\ Yogyakarta, Indonesia
}

*Corresponding Author’s Email: retha.ignaxandria@gmail.com

\begin{abstract}
Background: Children have a greater risk of experiencing medication errors than adults because they have a smaller body size so that the functions of the liver, kidneys and immune system are not impaired. Drugs' administration to children requires small doses, so nurses must be skilled in their calculations. Therefore nurses have an important role in preventing medication errors. Purpose: Explore nurses experience in pediatric medication safety. Methods: This is a qualitative research using purposive sampling along with data collection techniques with semi-structured interviews. This study was conducted by interviewing 8 nurses which included: 6 nurses, 1 charge nurse and 1 head of pediatric ward in one of the private hospitals in Yogyakarta. Results: This research found four themes: (1) nurses knowledge about medication administration safety, (2) responsibilities, roles and competencies of nurses in medication safety, (3) The weakness of nurses in carrying out medication safety and (4) nurse expectations. Conclusion: Nurses have resposibilities to increase medication safety in pediatric by improving nurse's knowledge and competency.
\end{abstract}

\section{Keywords: Nursing, Pediatric, Medication}

\section{INTRODUCTION}

Patient safety is an effort to prevent errors when delivering health care that can endanger patients. Every health worker can create mistakes in providing health services that may threaten patient safety and do harm to the patient. Procedure errors can occur in all lines of health services in all countries worldwide, both in developed and developing countries (WHO, 2015). A medication error is an error in the pharmacotherapy process that includes the process of ordering drugs, translating orders, administering drugs, and monitoring drugs (Antonucci \& Porcella, 2014). About $64.5 \%$ of medication error is carried out by nurses with one of the causes is nurse's lack of knowledge about the drugs (Cheragi et.al., 2013). Heavy workloads and work shifts are also the cause of medication errors in nursing practice (Fathi et.al., 2017).

Pediatric and neonate patient safety is vital because children, especially infants, have a greater risk in drug administration errors than adult patients (Koumpagioti et.al., 2014). Errors in the medication administration most often occur in critical care wards such as the Pediatric Intensive Care Unit (PICU) and Neonate Intensive Care Unit (NICU). Children who are treated in the PICU generally receive complex medication and care so that the incidence of errors in the medication administration might be 3 times more often than in adults (Kaushal, 2001). Nurses play a crucial role in patient care and preventing medication errors. One of the things that nurses can do is to implement the six rights principle of safe medication administration that includes right patient, right medication, right dose, right route, right time, and right documentation (Antonucci \& Porcella, 2014).

\section{METHODOLOGY}

This study used a qualitative descriptive design that aimed to describe the nurse experience in the implementation of the medication process in pediatric patients. This study was conducted in a pediatric ward in one of the private hospitals in Yogyakarta. The sample 
was nurses who were selected by a purposive sampling technique. There were 6 nurses as sample studies. We used source triangulation by conducting interviews with the head of the ward, the charge nurse in the pediatric ward, and the patient's parents. We used interview guidelines as an instrument to collect data that had previously been tested for understanding by conducting interviews with two nurses in the pediatric ward.

Data collection was conducted using semistructured interviews. We started by conducting an initial explanation of information about the study, thus respondents understood the investigation purpose and process, and then followed by informed consent. The interview was performed directly between investigators and participants. The interview process was recorded using a recording device on the cellular phone. After each interview, research assistants translated the results of the interview into a transcript. The investigators then read and recheck the completeness of the transcript and underline the matters that need to be asked again. Then, we continued the interview with the next participant and after that, we returned to the previous participant if any questions need to be asked again or to be deepened. We did member checking by asking participants, especially nurses, reading the transcripts that have been compiled and we asked them to provide comments and corrections.

The study was conducted after obtaining ethical clearance or letter of succeeding the ethical review for research from the Medical and Health Research Ethics Committee (KPEK) of Gadjah Mada University.

\section{RESULTS}

The participants were 6 nurses, 1 charge nurse and 1 head of pediatric ward. This study was conducted by interviewing 8 nurses. The results of this study found 3 themes: (1) nurses' knowledge about medication administration safety, (2) responsibilities, roles and competencies of nurses in medication safety, (3) The weakness of nurses in carrying out medication safety and (4) nurse expectations.

\section{Nurse's Knowledge of Medication Safety in Drug Administration}

Nurses felt that knowledge about the drugs given to patients was essential, thus when administering drugs to patients the nurse understands the type, dosage of the drug to be given. The administration of drugs was not just a routine duty but also requires excellent knowledge related to the drugs.
We shouldn't be careless when administering the drugs; we should also learn about the type of drug is, what the dosage is, what the dose given is, and how to administer it (Participant 2)

If the drugs given were classified as high-alert drugs, the nurse must use personal protective equipment (PPE). When administering high-risk medications, nurses must check carefully and 2 people must carry out the task (double-check).

Yes, if the drug is high alerts, we do use PPE (Participant 4)

Double-check ... if we administer high alerts drugs, we will check again with other colleagues (Participant 3 and Participant 6)

According to the rules of patient safety, the high alert drugs should be double-checked and, it must be documented (Participant 2)

In addition to know how to improve safety when administering high-alert drugs, nurses also understood the risk of administration of antibiotic drugs is causing allergies, thus before administering it, nurses performed a skin test first to determine whether the patient is allergic to the drug or not.

For antibiotic drug, we should perform the skin test first (Participant 4)

For antibiotic drug injection, we usually do the skin test first. Yes, we observe a quarter of an hour if there are signs of allergies or not. If there are signs of allergies, we usually call the doctor to consult other alternative medication (Participant 6)

To maintain patient safety when administering drugs, nurses used guidelines in the form of six rights principle, consisting of right patient, right drug, right dose, right route, right time and right documentation. Ward nurses also knew about standard operating procedures (SOPs) for drug administration to patients.

The six rights consist of the following drug administration must be correct, right dose, right time, right patient, right route, and right documentation (Participant 4 and Participant 6)

We know the SOP, but the SOP is only limited to process of administration of oral medication and how to administer intravenous injection drugs, that's all (Participant 2). 


\section{Nurses' Competencies, Roles, and Responsibilities in Medication Safety}

\section{Competency}

One of the specific competencies that must be owned by nurses in the pediatric ward was the ability and accuracy to calculate drug dosages. It was performed to avoid errors in the administration of drugs.

Maybe we must calculate the dose more carefully. Administration of medication also must be seen and must be careful (Participants 3, 5 and 6)

Nurses must also be able to operate equipment in the pediatric ward such as infusion pump and syringe pump.

Particular skills, usually infusion pump and syringe pump (Participant 5)

Pediatric patients need a special approach when performing some procedures. So, nurses in the pediatric ward must also be able to approach pediatric patients. When nurses administer drugs, the nurses must see to that so that the patients are cooperative when given the drugs.

Yes, maybe that approaches earlier. In this hospital, for example, when we give the drugs sometimes we don't say we will administer drug for injections. They are so afraid of the needle or something like that. At most, we say that we want to fill up the gasoline. But, actually, we told his/her mother that this is an antibiotic drug. For me, I rarely say I will inject the drug (Participant 3)

\section{Roles and Responsibilities of Nurses}

One of the roles and responsibilities of nurses in medication safety was to assess the patient's medical history. An assessment was conducted to obtain data about the patient's medical history.

Assessment, we usually ask at the beginning if there is a drug allergy or not, for example, if the patient is allergic, we cross-checked with a drug that will be administered, if there is no content in the drug that he/she had a history of allergies, immediately we administer it. Also, we usually ask about the history of treatment that has ever been given, history of illness that make him/her hospitalized, history of treatment for tuberculosis or was there any routine treatment from a family doctor (Participants 7 and 8)

Nurse was also responsible for checking the drugs that will be given to patients, including the name of the drug, the dosage of the drug, the route of administration of the drug, the patient's name and the date of birth of the patient to maintain patient safety.

"We prepare the drug first, then we maintain the patient safety principle, we ensure the drugs, the patient's name matches with the drug given, the dosage, and how to administer it" (Participant 2)

"Firstly, we check the drug, what the dose is and what the name is. Use it, uh... there's the patient label. "Yes, etiquette is the name, and the date of birth, the type of drug and the dose is already following the instruction of drug given by doctor," (Participant 7).

The nurse also ensured that the drug preparation process was performed properly. This was done by preparing the drug in front of the patient, preparing one drug per one patient, putting the patient's medication in a separate place from the other patients, preparing and administering the drug by the same nurse and labeling the drug he/she prepared.

"The medication or injection should be prepared in front of the patient, so we only bring the drugs and the instruments, after that we will prepare it in front of the patient's room. Sometimes, the children are afraid that if we prepare the injection in front of them, so we may prepare the drug behind the curtain or maybe outside the room. What should we do with the VIP room? We are mixing the drug and preparing the medicine there also, so it becomes one patient one drug, not collective, thus we don't bring many drugs. If there are a lot of drugs, for example, one patient has several kinds of drugs we will give the drugs a labeling "(Participant 2)

Awareness of nurses to maintain safety and minimize the occurrence of medication errors was also perform when giving medicines with due regard to the principle of six rights which includes right patient, right drug, right dose, right route, right time, and right documentation.

Yes, nurses must be mastering six rights principle properly, so if they master it, I'm sure there will be no mistakes (Participant 1)

Anyway, I mentioned six rights principle while we documented and cross-checked with the patient (Participant 5) 


\section{The Weakness of Nurses in Carrying Out Medication Safety}

When the nurses administering the drugs, there were situations or circumstances where nurses cannot perform the duty as the standards, for example, when conducting assessments, nurses do not conduct a complete medication assessment, so some data were blank. This was due to lack of motivation or high workload, so nurses failed to conduct a complete assessment.

Maybe because not all nurses feel it is important to do that ... sometimes I observe there are still empty assessments ... maybe it is not done because they are in a hurry to do something else ... yes, a lot of other work needs to be done (Participant 1)

The nurse also stated that they did not document correctly due to the fact that complete documentation had not yet become a culture of nurses in the ward. Too small documentation column also caused nurses to make incomplete documentation.

"Everybody has their own business; if everyone writes like that then the work will not be finished... Yes, because the column is so small that sometimes it's better with the name if it's a crosscheck. For example, the name is already clear, and all this time I also write only names ... it is a habit too. That is the obstacle if everything is like that, work does not finish "(Participant 3)

The head of the ward stated that not all nurses provide education about medication to patients and their families because of the lack of nurses' knowledge about drugs. The habit of educating patients and families about medication had not yet become a culture due to the large amount of work that must be done.

"Yes, because... maybe not all of us know about drugs. It might take time to study it, for example, when patient receive 4-5 drugs, it means we must learn the 5 drugs, however nurses might not learn too much about drugs ... ... it hasn't just been entrenched yet, and the nurses might not have mastered all the drugs and their function ... "(Participant 1)

\section{Nurse's Expectation}

Nurses in the pediatric ward expected special training for pediatric nurses in order to maintain the medication safety for patients.

If only nurses in the pediatric ward can attend trainings (participant 6)
Nurses also expect an increase in the number of nurses and equipment in the ward.

Recruit more nurses or presence of complete equipment such as injection box (participants 4 and 5 )

\section{DISCUSSION}

\section{Nurse's Knowledge of Medication Safety in Drug Administration}

Nurses' knowledge about medication is vital to prevent medication errors. A person's knowledge is influenced by the level of education and experience, in this case work is experience (Notoatmojo, 2012). Nurses who have a long work period and have a high educational background have better knowledge of medication (Simonsen, 2011). Nurses need to apply medication safety practices every day based on their knowledge and experience. Lack of knowledge and experience are the cause of medication errors (Wei, et.al. 2015). The medication errors are more often performed by nurses who have less knowledge and brief work experience (Hughes \& Blegen, 2008).

Nurses' knowledge about six rights principles is a guide to nurses in carrying out drug administration. If the nurse's knowledge of the six rights principle is proper, the nurse would apply the six rights principle correctly when administering drugs. This is supported by the results of research conducted by Harmiady (2014) which showed a relationship between nurses' knowledge and the implementation of the six rights principle in drug administration which means that nurses with good knowledge tend to implement the six rights principle appropriately at the time of drug administration.

Almost all nurses stated that double-checking was performed on certain drugs such as high-alert drugs. Medications that need to be watched out are drugs that have a high risk of error or causing undesirable effects (Ministry of Health Republic of Indonesia, 2011). It is important for nurses to check high-risk drugs and based on nurses' knowledge about drugs that are categorized as high-risk drugs so that nurses can minimize the medication errors. Antibiotic drugs are drugs that are prone to cause allergies. So before the patient gets the medication the nurse perform the skin test first. Nurses' knowledge about the types of drugs is also the basis for preventing medication errors. 


\section{Nurses' Competencies, Roles and Responsibilities in Medication Safety}

\section{Competency}

The pediatric ward is a special ward that requires specific competency of nurses. Pediatric patients have different complexities, due to various factors such as smaller body size. Moreover the functions of the liver, kidneys, and immune system do not function perfectly. Dosage form and packaging are generally intended for adults so that it differs in concentration. Children who are too young will have difficulty in communication so that the ability to inform the effects of drugs is constrained (Koumpagioti et al., 2014). Nurses in the pediatric ward must be able to calculate drug dosages correctly because pediatric patients tend to get smaller doses than adults. Providing drugs to pediatric patients often requires equipment such as infusion pump and syringe pump so that nurses are also required to be skilled in operating that specialized equipment.

The right approach to children and families will also facilitate nurses in administering drugs. The gentleness of the nurse and along with praise and appreciation towards the child is important while giving medication to the child. The nurse must explain the medication given to the child politely and gently. They must explain if the medication causes any discomfort. Praising and appreciating the child will make him or her more willing, will increase the cooperation and can pass the medication procedure well (McKinney \& James, 2014).

\section{Roles and Responsibilities of Nurses in Medication Safety}

Nurses must check for drug allergies, possible drug interactions and determine the right medication. Thus assessing the history of medication by nurses has a major role in achieving medication safety (Center Technology and Aging, 2010). It is important to assess the patient's treatment history to determine the appropriate treatment and assess the effectiveness of the drugs that have been used and prevent drug allergic reactions so that it may prevent medication errors to the patients. Hughes \& Blegen (2008) stated that one of the causes of medication error is an incomplete patient's medical history.

Nurses have a role to check the order of drug given including the name of the drug, dosage, route, and frequency of administration (CRNBC, 2015). The nurse must check the drug to prevent medication errors. Nurses' awareness of patient safety is the reason nurses must check the drugs to be given. According to Potter \& Perry (2010), nurses must check the drug label 3 times, before removing the drug packaging from the cupboard or medicine storage, before taking the amount of medicine from the bottle and after taking the amount of medicine from the bottle.

Nurses realize that to prevent medication errors, nurses must apply the six rights principle. Research conducted by Rahayu (2016) showed that all nurses in the pediatric ward implement five rights principles when giving medication that includes right patient, right medication, right dose, right route and right time, while not all nurses perform right documentation. The critical issue that nurses must pay attention to when giving a drug is the six rights principle which includes right patient, right medication, right time, right dose, right route and right documentation (Hughes \& Blegen, 2008; Department of Health Government of Western Australia, 2013). Giving drugs by applying the six rights principle also gives satisfaction to the patient; this is evident in research conducted by Kartika \& Melani (2018) that shows that $50 \%$ of patients are satisfied with the application of the six rights principle when administering the drug. Nurses are the health workers who most often find and detect medication errors in the prescription order phase before being given to patients. Medication errors can be prevented if in giving medicine the nurse always implements the six rights principle which includes right patient, right medication, right dose, right route, right time, and right documentation (Antonucci \& Porcella, 2014).

\section{The weakness of nurses in carrying out medication safety}

There are situations where nurses cannot work according to standards when implementing the nursing practice, especially when reviewing, documenting and providing education to patients and families. Lack of motivation, too high workloads, and a lack of knowledge of nurses about drugs become obstacles for nurses to work according to standards. Nurses have an important role to provide health education about the medication that will be given by considering the ability and understanding of patients for the drugs to be given (CRNBC, 2015). Providing education about treatment and involving patients and families in treatment helps reduce medication errors and improve medication safety (WHO, 2011). Nurses' knowledge about treatment is still lacking, especially in terms of calculating drug dose, drug management and pharmacology (Simonsen, 
et.al., 2014). This prevent nurses from providing education to patients.

\section{Expectation}

Nurses expect that they receive training specifically on pediatric nursing and they expect an increase in the number of workers and adequate equipment so that nurses can work according to standards. Nurse performance is related to nurse workload where nurses' heavy workload causes less performance (Manuho, Warouw \& Hamel, 2015). Several factors can affect the performance of nurses, one of which is the ability/competency of employees (Kuswandi, 2005). Ability/competency can be improved through education and training where education and training are expected to increase effectiveness of employees in their work. So, they can carry out their duties and work well. Education and training influence the performance of nurses where the performance of nurses will increase if provided with continuous education and training (Aulia \& Sasmita, 2014).

Many factors can affect the occurrence of medication errors made by nurses. Lack of nurse knowledge (61.5\%) is the most common obstacle when administering drugs
(Lan et al., 2013). Too heavy workload, inadequate numbers of the workforce and workplace settings also cause the occurrence of medication errors along with other contributing factors namely nurse characteristics and work experience (Parry, Bariball \& While, 2014; Ulas, et al., 2015). Nurse's work experience in medication will reduce the risk of medication errors in nurses (Westbrook et al., 2011).

\section{CONCLUSSION}

Based on the results of the above study, it can be concluded that nurses have a role and responsibility for medication safety in patients, especially pediatric patients. So, improving nurse's knowledge about medication and increasing nurse competency through education and training are crucial.

\section{Conflict of Interests} interest.

The authors declare that they have no conflict of

\section{ACKNOWLEDGEMENT}

The authors are thankful to the institutional authority for completion of the work.

\section{REFERENCES}

Antonucci, R. \& Porcelia, A. (2014). Preventing medication errors in neonatalogy; Is it a dream? WJCP, 3(3), pp 37-44.

Aulia, R. \& Sasmita, J. (2014). Pengaruh pendidikan dan pelatihan kepuasan kerja dan kepemimpinan terhadap kinerja perawat rawat inap di RSUD Kabupaten Siak.

Center for Technology and Aging (2010). Medication management process. Retrieved from: www.techandaging.org

Cheragi, M.A., Manoocheri, H., Mohammadnejad, E. \& Ehsani, S.R. (2013). Types and causes of medication errors from nurse's viewpoint. Iranian Journal of nursing and midwifery research, 18(3), pp 228-31.

College of Registered Nurses of British Columbia (CRNBC) (2015). Medication: The nurse's role in dispensing, compounding and administering medication in British Columbia. Retrieved from: www.crnbc.ca

Department of Health Government of Western Australia. (2013). The six right of safe medication administration. Retrieved from: https:/ww2.health.wa.gov.au/ /media/Files/Corporate/general\%20documents/safety/ PDF/Medication\%20safety\%20resources/Six\%20rights.pdf

Fathi, A., Hajizadeh, M., Moradi, K., Zandian, H., Dezhkameh, M., Kazemzadeh, S. \& Rezaei, S. (2017). Medication errors among nurses in teaching hospitals in the west of Iran: what we need to know about prevalence, types, and barriers to reporting. Epidemiology and health, 39.

Harmiady, R. (2014). Faktor-faktor yang berhubungan dengan pelaksanaan prinsip 6 benar dalam pemberian obat oleh perawat pelaksana di ruang interna dan bedah Rumah Sakit Haji Makassar. Journal Ilmiah Kesehatan Diagnosis, 5(4), pp 2302-1721.

Hughes, R.G. \& Blegen, M.A. (2008). Medication administration safety. An evidence-based handbook for nurses. Agency for Healthcare resoursce, US. 
Kartika, I.R. \& Melani, V. (2018). Application of "Six Rights" on Medication Administration by Nurse and Patient Satisfaction. Indonesian Nursing Journal of Education and Clinic (Injec), 2(2), pp 178-183.

Kaushal, R., Bates, D.W., Landrigan, C., McKenna, K.J., Clapp, M.D., Federico, F. \& Goldmann, D.A. (2001). Medication errors and adverse drugs events in pediatric inpatients. JAMA, 285(16), pp 2114-2120.

Ministry of Health Republic of Indonesia (2011). Peraturan Menteri Kesehatan No. 1691 tahun 2011 tentang keselamatan pasien rumah sakit.

Koumpagioti, D., Varounis, C., Kletsiou, E., Nteli, C. \& Matziou, V. (2014). Evaluation of the medication process in pediatric patients: a meta-analysis. Journal de Pediatria (Rio J), 90(4), pp 344-355.

Kuswandi (2005). Cara Mengukur Kepuasan Kerja. Jakarta: Elex Media Komputindo. Retrieved from: http://kin.perpusnas.go.id/DisplayData.aspx?pId=14650\&pRegionCode=TRUNOJOYO\&pClientId=639

Lan, Y.H., Wang, K.W., Yu, S., Chen, I.J., Wu, H.F. \& Tang, F.I. (2013). Medication errors in pediatric nursing: Assessment of nurses' knowledge and analysis of the consequences of errors. Nurse Medication Today, 34(5), pp 821-828.

Manuho, E., Warouw, H. \& Hamel, R. (2015). Hubungan Beban Kerja Dengan Kinerja Perawat Dalam Pemberian Asuhan Keperawatan Di Instalasi Rawat Inap C1 Rsup Prof. Dr. RD Kandou Manado. Journal Keperawatan, 3(2).

McKinney, E. S., James, S. R., Murray, S. S., Nelson, K. \& Ashwill, J. (2017). Maternal-child nursing-e-book. USA: Elsevier Health Sciences.

Notoatmodjo, S. (2012). Promosi Kesehatan dan Perilaku Kesehatan. Jakarta: Penerbit PT Rhineka Cipta.

Parry, A.M. Barriball, K.L. \& While, A.E. (2014). Factors contributing to registered nurse medication administration error: a narrative review. IJNS, 52(1), pp 403-20

Potter, P.A. \& Perry, A.G. (2010). Fundamental Keperawatan. Salemba Medika.

Rahayu, M.H. (2019). Nursing Practice towards Pediatric Medication Process in Yogyakarta's Private Hospital Indonesia. KnE Life Sciences, 4(13), 550-557.

Simonsen, B.O., Johansson, I., Daehlin, G.K., Osvik, L.M. \& Farup, P.G. (2011). Medication knowledge, certainty, and risk of error in health care: a cross-sectional study. BMC Health Service Research, 11:175.

Ulas, A., Silay, K., Akinci S, Dede, D.S., Akinci, M.B., Sendur, M.A.N., Cubukcu, E., Coskun, H.S., Degirmenci, M., Utkan, G., Ozdemir, N., Isikdogan, A., Buyukcelik, A., Inanc, M., Bilici, A., Odabasi, H., Cihan, S., Avci, N. \& Yalcin, B. (2015). Medication errors in chemotherapy preparation and administration: a survey conducted among oncology nurses in Turkey. Asian Pacific Journal of Cancer Prevention, 16(5), pp 1699-1705.

Wei, L.Y., Min, T.H., Ming, E.J.C., Sheng, J.Y.B. \& Ahmad, K. (2015). Qualitative research on medication safety among nurses and pharmacists in hospital miri. Sarawak Journal of Pharmacy, 1, pp 1-12.

Westbrook, J.I., Rob, M.I., Woods, A. \& Parry, D. (2011). Errors in the administration of intravenous medications in hospital and the role of correct procedures and nurse experience. BMJ Quality \& Safety, 20(12), pp 1027-1034

World Health Organization (WHO) (2015). Indonesia: Statistical profile. Geneveva, Switzerland: Secretariat. 